ORIGINAL RESEARCH PAPER

\section{STUDY OF SERUM LIPASE TO AMYLASE RATIO IN DIFFERENTIATING BETWEEN ACUTE ALCOHOLIC AND NON-ALCOHOLIC PANCREATITIS}

\section{Surgery}

KEY WORDS: Acute

Pancreatitis, Alcoholic

Pancreatitis, Non-alcoholic

Pancreatitis, Amylase, lipase

\section{Dr Sudhansu}

Sarkar*

\section{Dr Bala Krishna} Havligi

\section{INTRODUCTION}

Acute pancreatitis (AP) is a common condition involving the pancreas. The estimated incidence is about $3 \%$ of cases presenting with pain in abdomen. ${ }^{(4)}$ Gall stones and alcoholism together account for $80 \%$ of acute pancreatitis. ${ }^{(5)}$ Although the overall mortality rate for acute pancreatitis is 2$10 \%$ and this is primarily related to the $10-30 \%$ of patients with severe disease characterized by pancreatic and peripancreatic necrosis. ${ }^{(6)}$ Diagnosis remains clinical and can be supported by 1.5 - 2 fold increase above the upper limit of normal of serum amylase and lipase. ${ }^{(10)}$ Amylase and lipase levels are known to be the most important factors in determining acute pancreatitis. It is well known that these levels are usually elevated in acute pancreatitis, without regard to whether it is of biliary type or alcoholic type. Furthermore whether or not these levels can be used to discern between the two types, has been also a matter of concern. It has been reported that the lipase/amylase ratio could be a new index distinguishing two types of pancreatitis, with the critical value being 2 . This report had been followed by some debate between supporters and opponents. Currently CECT is the imaging modality of choice where areas of hypo perfusion correlate with necrosis. ${ }^{(1)}$ It can't differentiate between alcoholic and non-alcoholic AP. Identification of two groups could help formulating treatment protocol for either group. The aim of the present study is to establish the utility of the ratio of the serum lipase and serum amylase, a new index distinguishing acute episode of alcoholic from non alcoholic pancreatitis.

\section{Aims \& Objectives}

\section{General Objective:}

The ratio of serum lipase to serum amylase has been proposed to distinguish between acute episodes of alcoholic from non-alcoholic (gall stone) pancreatitis

Specific Objective:

1. To estimate the Lipase/amylase Ratio for each study subject

2. To determine the sensitivity and specificity of serum lipase/amylase ratio in predicting between alcoholic and non-alcoholic(gall stone) pancreatitis

\section{Materials and Methods}

\section{STUDY DESIGN:}

It was a hospital based descriptive cross sectional study in predicting The serum Lipase/amylase ratio had been proposed to distinguish the aetiology of acute pancreatitis, the efficacy to predict the sensitivity and specificity by lipase/amylase ratio of acute pancreatitis is assessed in this study among the patients sustaining with acute pancreatitis. Total 65 patients will be included in this study.

\section{STUDY SETTING \& STUDY PERIOD}

This study was conducted in the In-Patient-Department of General Surgery of BSMCH, Bankura. The study was accomplished in a stipulated time frame of one and half year i.e. from February, 2018 to July, 2019 .

www.worldwidejournals.com

\section{INCLUSION CRITERIA:}

1. Patient with history of alcohol intake without cholelithiasis of above 18 years of age

2. Patient with history of cholelithiasis without alcohol intake of 18 years of age

\section{EXCLUSION CRITERIA:}

1. Patients with Severe acute pancreatitis were deleted from the study.

2. Patients with both alcoholism and cholelithiasis in a Single Patient were also excluded from the study.

3. Patients with chronic pancreatitis and acute on chronic pancreatitis

\section{RESULT \& ANALYSIS}

In our study mean age of the patients was $35.90 \pm 8.25$ with median of 35.00. Those who were suffering from alcoholic pancreatitis all were male and there total number is $51(78.46 \%)$. In non-alcoholic gr. There were $14(21.54 \%)$ patients.

It was seen that $78.46 \%$ of the patient were diagnosed with acute alcoholic pancreatitis with history of Alcoholic addiction and remaining $21.54 \%$ patients were diagnosed with the absence of alcohol addiction were diagnosed as non-alcoholic pancreatitis especially gall stone pancreatitis with history of cholelithiasis.Ultrasonography showed cholelithiasis in these patients.

Table-1: Distribution of participants according to serum amylase levels. $(n=65)$

\begin{tabular}{|l|l|l|l|}
\hline Group & Mean & $\begin{array}{l}\text { Standard } \\
\text { Deviation }\end{array}$ & Independent t, df, p \\
\hline Alcoholic & 656.5471 & 164.4311 & $1.115,1,=0.2496$ \\
\hline Non-alcoholic & 711.1571 & 154.1602 & \\
\hline
\end{tabular}

The mean amylase in alcoholic pancreatitis group is $656.5(\mathrm{SD}=164.3)$ which is significantly lower but statistically not significant at $95 \%$ confidence interval than mean of nonalcoholic pancreatitis which is $711.1(\mathrm{SD}=154.1)$ at $95 \%$ confidence interval.

Rise of serum amylase in non-alcoholic pancreatitis is significantly higher than that in alcoholic pancreatitis. but not statistically significant at $95 \%$ confidence interval.

Table-2: Distribution of participants according to Lipase levels. $(n=65)$

\begin{tabular}{|c|c|c|c|}
\hline Group & Mean & Standard Deviation & $\begin{array}{l}\text { Independent } t \text {, } \\
\text { df, p }\end{array}$ \\
\hline Alcoholic & 1464 & 734 & \multirow{3}{*}{$\begin{array}{l}-3.107 \\
63,<0.0001\end{array}$} \\
\hline Non-alcoholic & 543 & 214 & \\
\hline Total & 1707 & 948 & \\
\hline
\end{tabular}

The mean lipase level in alcoholic pancreatitis is 1464.1 which is higher but statistically significant than that in non-alcoholic pancreatitis 543.7 at $95 \%$ confidence interval.

After running ANOVA Test we found that mean lipase levels in 
alcoholic pancreatitis is higher than in non-alcoholic pancreatitis but statistically significant at $95 \%$ confidence interval.

Table-3: Data comparison between the Alcoholic Pancreatitis and Non-Alcoholic Pancreatitis. (n=65)

\begin{tabular}{|c|c|c|c|}
\hline & \begin{tabular}{|l|} 
Alcoholic \\
Pancreatitis
\end{tabular} & \begin{tabular}{|l|} 
Non-Alcoholic \\
Pancreatitis
\end{tabular} & P value \\
\hline Age(Meant SD) & $35.9020 \pm 8.2565$ & $51.8571 \pm 6.5499$ & $<0.001$ \\
\hline Sex ratio (M:F) & $(49: 2)$ & $(5: 9)$ & $<0.0001$ \\
\hline $\begin{array}{l}\text { Serum } \\
\text { amylase(Mean } \\
\pm \text { SD) }\end{array}$ & $\begin{array}{l}656.5471 \pm 164.4 \\
311\end{array}$ & $711.1571 \pm 1602$ & $=0.269$ \\
\hline $\begin{array}{l}\text { Serum } \\
\text { lipase(Mean } \pm \\
\text { SD) }\end{array}$ & $\begin{array}{l}1464.1176 \pm 734 \\
8193\end{array}$ & \begin{tabular}{|l|}
$543.7143 \pm 214.4$ \\
666
\end{tabular} & $=0.003$ \\
\hline $\begin{array}{l}\text { Serum } \\
\text { lipase/amylase } \\
\text { ratio(Mean士 } \\
\text { SD) }\end{array}$ & $2.2300 \pm 0.2586$ & $.7645 \pm 0.2416$ & $<0.001$ \\
\hline
\end{tabular}

Table-4: Distribution of participants according to Serum Lipase/Amylase Ratio and the type of pancreatitis

\begin{tabular}{|l|l|l|l|l|l|}
\hline $\begin{array}{l}\text { Type of } \\
\text { pancreatitis }\end{array}$ & mean & $\begin{array}{l}\text { Standard } \\
\text { deviation }\end{array}$ & $\begin{array}{l}\text { Indepen } \\
\text { dent t } \\
\text { value }\end{array}$ & $\begin{array}{l}\text { Degree } \\
\text { of } \\
\text { freedom }\end{array}$ & P-value \\
\hline $\begin{array}{l}\text { Alcoholic } \\
\text { pancreatitis }\end{array}$ & 2.2300 & 0.2586 & 6.925 & 63 & $<0.0001$ \\
\cline { 1 - 3 } $\begin{array}{l}\text { Non- } \\
\text { Alcoholic } \\
\text { pancreatitis }\end{array}$ & .7645 & 0.2416 & & & \\
\hline Total & 2.7132 .4002 & --- & -- & -- \\
\hline
\end{tabular}

1. Sensitivity $=a / a+c \times 100=47 / 51 \times 100=92.2 \%$

2. Specificity $=\mathrm{d} / \mathrm{b}+\mathrm{d} \times 100=12 / 14 \times 100=85.7 \%$

3. Positive Predictive Value $=a / a+b \times 100=47 / 49 \times 100=95.91 \%$ 4. Negative Predictive Value $=\mathrm{d} / \mathrm{c}+\mathrm{d} \times 100=12 / 16 \times 100=75.0 \%$

\section{DISCUSSION}

In our study, the number of alcoholic pancreatitis were seemed to $78 \%(n=51)$ of the total patients that is higher than non-alcoholic pancreatitis (Gall stone Pancreatitis) with 22 $\%(n=14)$ of the total patients Comparable to western literature.Wu et al reported that most of these cases with acute pancreatitis were between the age of 21 to 40 years old, which accounted $57.7 \%$ of the total cases and $64.1 \%$ of female cases was in age groups of 21 to 30 years old,which was much younger than reported in other Asian countries However, there was no documented report comparing the different etiologic groups. In our study the patients with alcoholic AP were relatively younger than non- alcoholic AP patients. The alcoholic AP patients were ranging between 20 to 45 years with mean age 36 years \pm 8 years while the non-alcoholic AP ranges between 40 to 65 years with the mean age 52 years \pm 7 years. Little bit Similar findings were observed in other studies.

Our study findings were concurrent with others with respect to the alcoholic pancreatitis being predominantly seen in males with $75 \%(n=49)$ when compared to females with the $3 \%(n=2)$, while the biliary AP was higher amongst the females with $15 \%(n=10)$ in comparison to males $6 \%(n=4)$. Probably the reason could be that the percentage of alcoholics reported is lower for females when compared to males in Indian population and the reported cases of AP in females for other causes of pancreatitis such as biliary is much higher than the alcoholic variety.

Earlier studies showed that rise in serum of amylase in alcoholic pancreatitis were significantly lower than in gall stone pancreatitis. Serum lipase levels were not statistically different. Our study demonstrates similar results that is increase of serum amylase in gall stone pancreatitis is significantly higher than that in alcoholic pancreatitis while mean lipase levels in alcoholic pancreatitis is higher than in gall stone pancreatitis with statistically significant $95 \%$ confidence interval.

Our results show that serum Lipase/Amylase ratio with a cut off value fixed at 2 , can assist in differentiating alcoholic AP from non-alcoholic AP. The lipase / amylase ratio $>2$ is observed in alcoholic AP while the non-Alcoholic (Gall stone pancreatitis) ratios $<2$. Our reports showed sensitivity of 92 $\%$ and specificity was $85 \%$ with lipase / amylase ratio $>2$. to alcoholic AP. Our results show that serum lipase/amylase ratio with a cut off value fixed at 2 , can assist in differentiating alcoholic AP from non-alcoholic AP.

\section{CONCLUSION}

We would like to conclude that serum lipase/amylase ratio more than 2 could be used to differentiate acute alcoholic pancreatitis and values less than 2 as acute non-alcoholic (gall stone) pancreatitis. Hence serum lipase/amylase ratio may be useful as means of biochemical diagnostic tool to differentiate alcoholic from gallstone pancreatitis in acute pancreatitis setting in the back-ground of relevant clinical and radiological assessment. This shall help in better triage of patient in emergency department.

\section{REFERENCES}

1. Fitz R. Acute Pancreatitis: a consideration of pancreatic hemorrhage, hemorrhagic, supurative and gangrenous pancreatitis, and of disseminated fat necrosis. Boston: 1889 .

2. Opie E. The etiology of acute hemorrhagic pancreatitis. Bull John Hopkins Hospital. 1902; (74):398-401.

3. Thomson SR, Hendry WS, McFarlane GA, Davidson AI. Epidemiology and outcome of acute pancreatitis. Br J Surg. 1987;74(5):398-401.

4. Kuo-Chin Chang, Chi-Sin Changchien, Chung-Mou Kuo, Yi- Chun Chiu, SengKee Chuah, King-Wah Chiu, Chung-Huang Kuo. Clinical analysis of the efficacy in Lipase/Amylase ratio for acute pancreatitis. J Intern Med Taiwan 2005; 16: 113-20.

5. King LG, Seeling CB, Ranney JE. The Lipase to amylase ratio in acute pancreatitis. Am J Gastroenterol 1995;90:67-9.

6. Tenner SM, Steinber WM. The admission serum lipase/ amylase ratio differentiates alcoholic from nonalcoholic acute pancreatitis. Am J Gastroenterol 1992;87:1755-58.

7. Gumaste VVl, Dave PB, Weissman D, Messer J (1991 Nov). Lipase/Amylase Ratio. A New Index That Distinguishes Acute Episodes of Alcoholic From Nonalcoholic Acute Pancreatitis Gastroenterology, 101(5):1361-6.

8. King LG, Seeling CB, Ranney JE.(1995). The lipase to amylase ratio in acute pancreatitis. Am J Gastroenterol , 90:67-9.

9. Kuo-Chin Chang, Chi-Sin Changchien, Chung-Mou Kuo,Yi- Chun Chiu, SengKee Chuah, King-Wah Chiu, Chung-Huang Kuo. Clinical analysis of the efficacy in Lipase/Amylase ratio for acute pancreatitis. J Intern Med Taiwan $2005 ; 16: 113-20$

10. King LG, Seeling CB, Ranney JE. The Lipase to amylase ratio in acute pancreatitis. Am J Gastroenterol 1995; 90:67-9.

11. Kazmierczak SC, Catrou PG, Van Lente F. Enzymatic markers of gallstone induced pancreatitis identified by ROC curve analysis, discriminant analysis, logistic regression, likelihood ratios, and information theory. Clin Chem 1995; 41:523-31.

12. Laurent-Puig $\mathrm{P}$, Boutron $\mathrm{A}$, Briantais MJ, et al. Lipase/amylase ratio in pancreatitis:an etiologic index? Gastroenterol 1992; 103:353-4.

13. Lankisch PG, Pertersen M. Lipase/amylase ratio: not helpful in the early etiological differentiation of acute pancreatitis.J Gastroenterol 1994;32:8-11.

14. Anitha Devanath, Jaya Kumari, Jim Joe, Saly Peter, Sugirtha Rajan, Laly Sabu, Shivshankar, Janet Mary, Smitha,Roselin, and Arokiasami. (2009 Oct) Usefulness of lipase / amylase ratio in acute pancreatitis in South Indian population. Indian J Clin Biochem, 24(4): 361-365.Published online 2009 Dec30.doi: 10.1007/s12291-009-0065-3.PMCID:PMC3453054. 